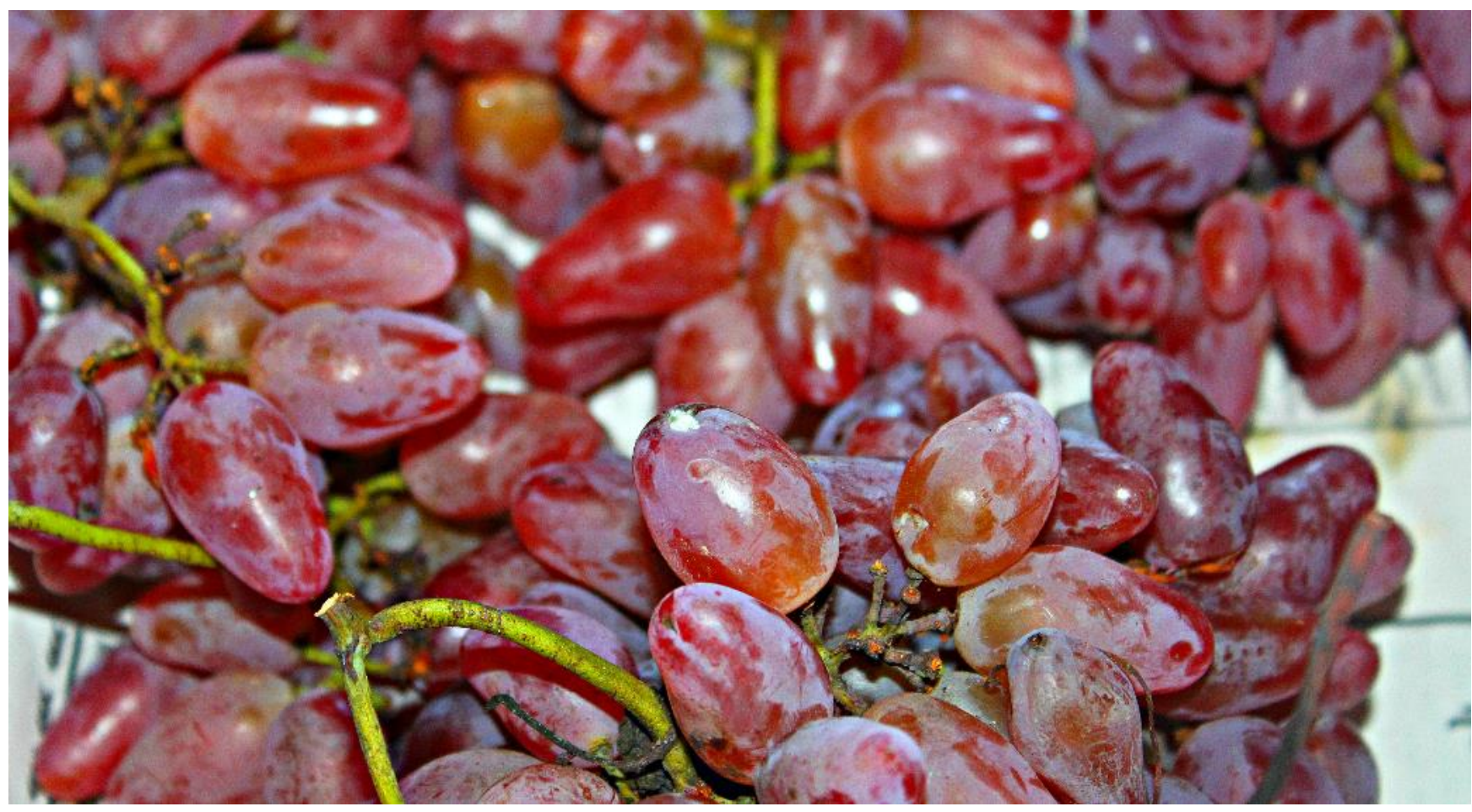

Grapes produced by small-scale farmers in Georgia. Photo: Nino Gvianishvili/Oxfam

\title{
A FAIR SHARE FOR GEORGIA'S GRAPE GROWERS
}

Poverty is widespread among the small-scale farmers and workers who produce and process our food, in an industry worth billions of dollars. Oxfam's new campaign highlights the systemic inequality and human suffering in food supply chains - and shows how action by supermarkets, governments, small-scale farmers and workers could lead to a decent and dignified standard of living for millions of people.

This case study describes how, despite the rapid growth of Georgia's wine industry, small-scale grape growers are continuing to live in poverty and are unable to develop their businesses or to profit from the industry they supply. It analyses the strengths and failings of previous and current government interventions, and offers recommendations on how they could be improved for long-term impact.

This is one of a series of case studies to supplement the global campaign report, Ripe for Change, drawing attention to the plight of specific groups of small-scale farmers and workers in international food value chains and/or promoting successful alternative approaches. 
Viticulture - the cultivation of grapes - is widely practised in Georgia, particularly in the country's eastern region: approximately 38,000 to 40,000 hectares is currently given over to grape production, and there are more than 35,000 small-scale grape growers. ${ }^{1}$ Georgia's wine exports are increasing rapidly, it exported $\$ 114 \mathrm{~m}$ worth of wine in 2016 - a $16 \%$ increase on 2015, and almost three times more than in $2010 .^{2}$

Georgian wine can now be found on supermarket shelves in many countries, with the top five export markets being Russia, Ukraine, China, Kazakhstan and Poland. ${ }^{3}$ Wine-related tourism is also increasing due to the popularity of local varieties of grapes and interest in traditional organic practices. ${ }^{4}$ Despite being a small player within the global wine market, Georgia's wine sector makes a significant contribution to the country's output, GDP and employment.

Georgia's growing wine industry has the potential to lift some of the country's poorest rural producers out of poverty. However, the distribution of benefits yielded by the sector is drastically unequal.

The problems facing smallholder grape growers reflect the wider situation in Georgia's agricultural sector. Over half of the population work in farming; the majority are women and/or small-scale farmers. ${ }^{3}$ They are currently the most economically vulnerable people in the country. As in other areas of crop production, the majority of small-scale grape producers use inefficient methods, have little access to high-quality inputs and services, and don't yet have the knowledge and skills necessary to compete in national and international markets. As a result, wineries are increasingly choosing to grow their own grapes to ensure a reliable, high-quality supply - further compounding the problems of small-scale producers and excluding them from the benefits of this increasingly profitable industry.

The grape-growing and wine-making sectors are interdependent, yet each is currently failing to support the other. The government and the wine industry must come together to facilitate effective communication and collaboration between grape growers and wineries. Small-scale grape growers need support to meet growing challenges and increase their productivity so that they too can prosper from the country's expanding wine sector.

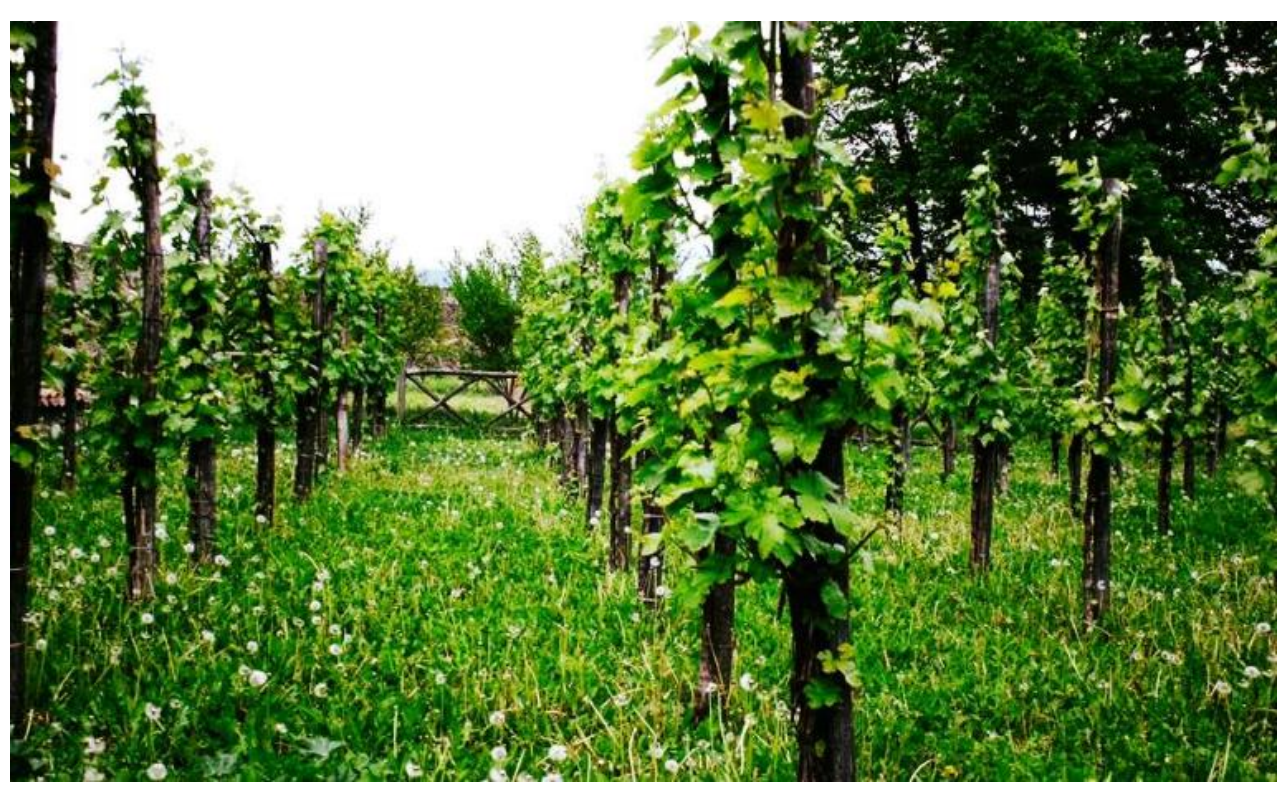

A vineyard in Georgia Photo: Nino Gvianishvili/Oxfam 


\section{WHY SMALLHOLDER GRAPE GROWERS STRUGGLE TO COMPETE BARRIERS TO PRODUCTION}

The majority of small-scale producers in Georgia (approximately 70\%) have less than 0.5 hectares of land. ${ }^{5}$ In viticulture and in the agricultural sector in general, land is highly fragmented and divided as a result of land reforms in the 1990s, following the collapse of the Soviet Union. The complex division and small size of vineyards acts as a major barrier to the development of efficient and sustainable production systems, resulting in high production costs and low yields for farmers.

These factors put farmers in a weak bargaining position, limit their access to capital resources, finance and markets, and prevent them from achieving economies of scale and fully reaching their potential. It is very risky for individual farmers to increase production due to high costs and the uncertainty of a successful harvest, especially given the increasing unpredictability of the climate. Smallholders are highly vulnerable to variations in production, simply because the income generated by smallscale farming is so low; they have no savings to fall back on or to repay debts with if harvests are poor.

The combination of low production and high variability in output and price creates fluctuations in incomes, which can be devastating for rural households whose main or only source of income is agriculture.

A grape growers' income depends on whether (and how much) they sell to wineries or whether they make and sell their own wine. It also depends on the varieties of grape they sell to wineries, as different varieties fetch different market prices. Bulk wine produced by smallholders themselves is mostly for local consumption. It sells for much less than wine produced in wineries, which is bottled, labelled and branded, and satisfies the technical requirements necessary to appeal to tourist and export markets. ${ }^{6}$ Over the last decade, many grape growers have also relied on government subsidies (see below).

\section{GOVERNMENT SUBSIDIES LACK LONG-TERM VISION}

Since 2007, the Georgian government has been actively subsidizing grape growers by purchasing grapes directly from them at a higher than market price, ensuring they don't lose income due to unsold surplus production. For some years, the government reactivated the state wine company to purchase unsold grapes, especially during a Russian embargo of Georgian wines, which began in 2006 and ended in $2013 .{ }^{7}$ In 2011, 48\% of grapes were processed by the state company. In 2015 , the budget allocation to grape subsidies was around $€ 15 \mathrm{~m} .{ }^{8}$ While this government intervention has played an important role in protecting farmer incomes in the short term, it is unsustainable in the long run due to the enormous cost to the tax payer.

The scheme has also been criticised for failing to improve the sustainability of the viticulture sector. For example, it has been criticised for failing to
'I sell my grapes to wineries. The cost of production is high and the final selling price is not satisfactory. The market is not stable, and the cost of human capital is increasing every year.'

Small-scale farmer from the Khaketi wine region 
improve efficiency and productivity and for incentivising improvements in quantity, but not quality, of supply. This means that small-scale farmers risk loss of income and potential collapse if the government changes its approach.

It is critical that government interventions are designed to support smallscale farmers in international and national value chains to increase the share of the end consumer price they receive.

\section{THE IMPACT OF INTERNATIONAL MARKETS AND FREE TRADE}

Georgia's free trade agreement with the EU is bringing additional pressures to bear on smallholder grape growers. In 2014, Georgia signed the Association Agreement (AA) with the EU, and a 'Deep and Comprehensive Free Trade Area' (DCFTA ${ }^{9}$ ) entered into force in 2016. The DCFTA offers some useful opportunities - for example, it makes exporting to the EU easier and more lucrative by removing tariffs, and necessitates improvements to food safety and hygiene standards. However, it also opens up imports to Georgia, thereby increasing the competitive pressure on Georgian agriculture. This is particularly the case for smallholders, who are unable to export their produce because they lack the resources to comply with the EU's stringent food safety standards.

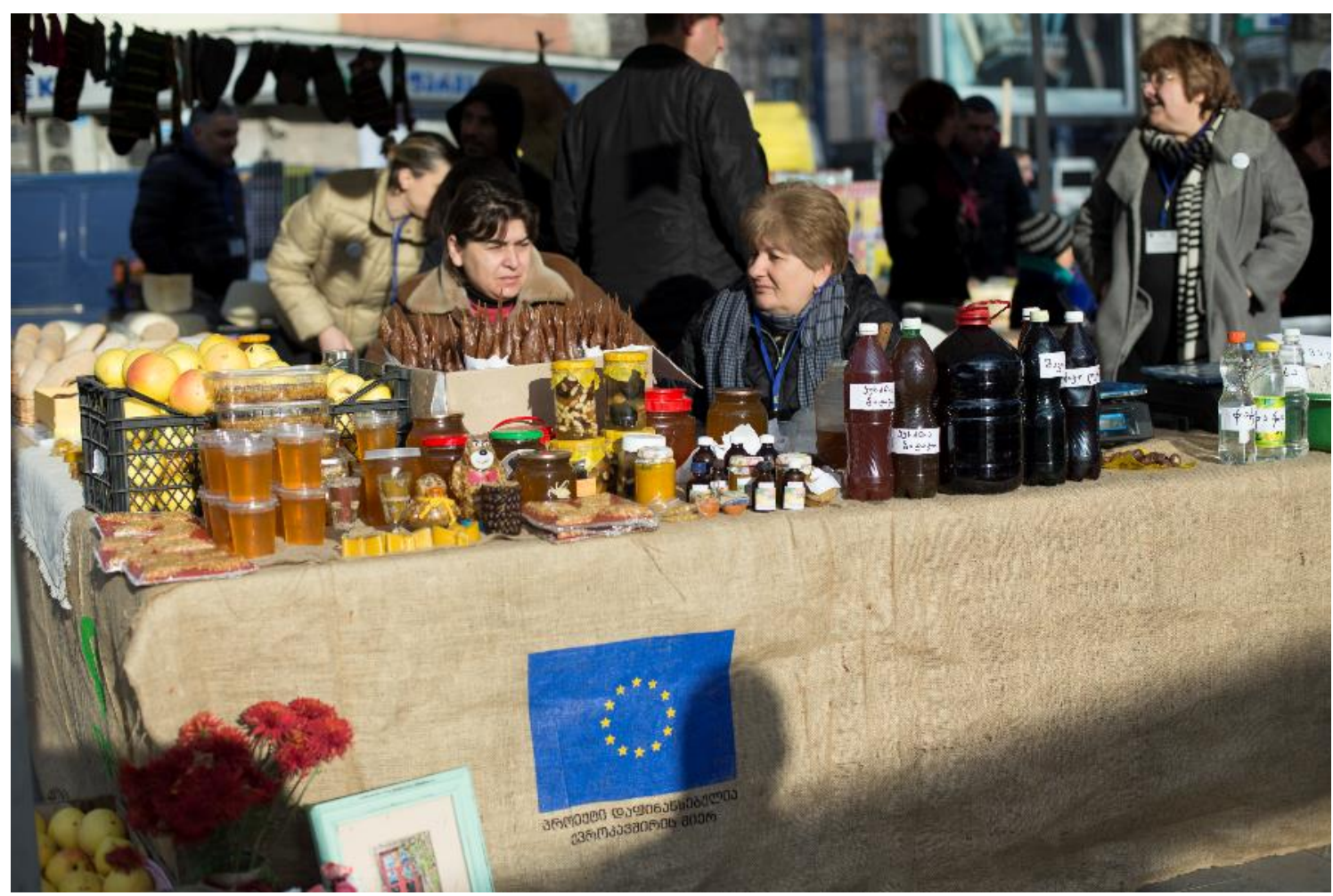

Small-scale farmers selling wine and other products at a market share event in Georgia. Photo: Nino Gvianishvili/Oxfam 


\section{HOW COOPERATIVES CAN \\ INCREASE THE SHARE OF VALUE FOR GRAPE GROWERS}

Working in cooperation with other growers is one of the most viable ways for small-scale grape growers to improve their production and increase their income.$^{10}$ In 2013, the Georgian government enacted the Law of Georgia on Agricultural Cooperatives, and has since taken significant steps to support cooperatives. These include tax benefits, co-financing of grant programmes, initiatives to enable farmers to access credit, training and consultation, and government subsidies to purchase equipment (e.g. mini tractors). ${ }^{11}$ Since 2013, more than 1,500 new cooperatives have been established, according to the database of the Agricultural Cooperatives Development Agency (ACDA). ${ }^{12}$

There are a number of advantages that may encourage more farmers to form cooperatives. These include sharing costs and risks, and gaining access to credit. Cooperatives are better able to form contractual relationships with trade partners, and being part of a cooperative can reduce the cost of finding new trade partners. Furthermore, cooperatives can help farmers to achieve economies of scale in production and gain market power. Compared to individual farmers, cooperatives have greater bargaining power, which enables them to purchase services, business supplies and other materials with a volume discount, and secure better prices for their product. However, cooperatives also come with challenges, and only work if the right infrastructure, management, support and skills are available.

Despite the government incentives for farmers to establish cooperatives, there are currently only 40 grape-processing cooperatives in Georgia, which are mostly funded by EU projects. Together they have 250 members, with a total of 316 hectares of vineyard land in ownership. ${ }^{13}$ This comprises a tiny share of the total of 40,000 hectares of vineyard in Georgia. One example of a successful viticulture cooperative is Winery Sazano (see Box 1).
'This kind of cooperation is a great opportunity to succeed in the viticulture sector. We opened the Wine Festival last year and have been invited to many international wine fairs. Soon we will start to export our wine to the Czech Republic.'

Member of the Winery Sazano cooperative

\section{Box 1: Reaching new markets - the Winery Sazano cooperative}

Winery Sazano was established in 2014, has ten members and cultivates five hectares of organic vineyard. In 2015, it received a capital investment grant of $€ 35,000$ from the EU's agriculture and rural development programme, ENPARD, ${ }^{14}$ to purchase wine-making machinery and increase its processing capacity. This has enabled the group to improve the quality of its wine, create its own brand, and market the wine internationally. A cooperative member describes why the approach has proved so successful:

'Before we joined the cooperative, we were individual farmers who processed wine for the local market, without any marketing image. With the shared desire to switch to organic wine, we formed the cooperative and have enjoyed many benefits that we would never have seen otherwise. The vineyards still remain in our ownership, but the production materials, tractors and wine-processing machinery, as well as the administrative costs, are shared. The wine produced by 10 different farmers is now marketed in Georgia under a single brand/cooperative name.

This kind of cooperation is a great opportunity to succeed in the viticulture sector. We opened the Wine Festival last year and have been invited to many international wine fairs. Soon we will start to export our wine to the Czech Republic.' 
However, despite the potential of cooperatives to increase productivity, and the government's important steps to create a supportive environment for cooperatives, the older generation of farmers have misgivings about the system, believing it to be a replica of the old Soviet-style 'collectivization'. This is reflected in the testimony of a smallholder grape grower from the Khaketi wine region:

I produce grapes on 1.3 hectares of vineyard and sell to wineries near my village. I know that even if I wanted to produce wine, I could not compete independently with big wineries in the market. Consolidating vineyards with neighbours by forming a cooperative might allow me to share production costs (such as machinery and chemicals) and gain a couple of other privileges that the state gives to cooperatives. However, being part of a cooperative is not easy - it requires double work and responsibility. I still doubt whether I want to do that, and would prefer to stay an independent farmer.'

Another farmer from the same region said:

'I would like to form a cooperative but the reason I am staying an independent producer is because I could not find people who I could trust to do my business with.'

It is therefore important that any efforts to support cooperatives also aim to change such perceptions, and to demonstrate to farmers that the new cooperative system is based on principles of independence, democracy and members' economic participation. Box 2 gives an example of a recent government intervention that aims to enable viticulture cooperatives to increase their share of the end consumer price.

\section{Box 2: From grapes to wine - a new government initiative for viticulture cooperatives}

In response to Oxfam's programme and advocacy in Georgia, in 2017 the Georgian government launched a pilot programme, 'Supporting viticulture cooperatives', with a total budget of $€ 300,000 .{ }^{15}$ The programme's main objective is to give farmers access to capital assets, so that instead of being dependent on wine processors, farmers can process grapes themselves, ensuring that they reap the maximum value from their produce. Grape growers' cooperatives that meet the necessary criteria are provided with machinery for the primary processing of up to 100 tonnes of grapes. This type of government intervention is expected to enable the cooperatives to decrease their dependency on wineries and capture additional value by developing their own wines. 


\section{CONCLUSION AND RECOMMENDATIONS}

Higher agricultural output is one of the best strategies for poverty alleviation for thousands of households in rural areas of Georgia. By combining their capital and efforts, smallholders will be able to achieve greater efficiency in the sector and create added value. Government intervention - with targeted investment and technical assistance schemes - is essential to successfully develop agricultural cooperatives over the long term.

In Georgia, within the EU funded ENPARD programme, Oxfam provides assistance and expertise to cooperatives, while trying to change and improve the policy environment for the long-term benefit of smallholder farmer cooperatives. Oxfam in Georgia has been calling for the following improvements in the policy environment:

- Increase government support which is tailored to the needs of smallholder farmers and cooperatives, in order to empower them within markets and give them the opportunity to add value to their produce.

- Promote and increase the capacity of cooperatives, rather than just increasing the number of organizations with the legal status of cooperative.

- Increase the budget allocation of the Agricultural Cooperatives Development Agency (ACDA) for cooperative services (extension/financial services, etc.).

- Adopt policies that provide tax incentives to cooperatives in the long term.

- Ensure that agricultural development policies and programmes are gender sensitive, and integrate a gender perspective into the agricultural development strategy.

For the viticulture sector in particular, Oxfam recommends the following:

- Promote production-input cooperatives (for joint grape production) and processing cooperatives (for processing and wine making) to enable grape growers to scale up production and benefit from value addition.

- Strengthen grape growers' professional skills and knowledge by increasing opportunities for them to receive advice from experienced professionals, and by improving the efficiency of state extension services and information/consultation centres.

- Ensure that extension services and other support is accessible for women, based on women's expressed needs, taking into account their time and other constraints (e.g. transport, time of day, domestic responsibilities, etc.).

Through its new campaign, Oxfam is calling for an end to human suffering in supermarket supply chains, and promoting alternative business models that give the people behind the products a fair share of the value. To find out more about the campaign, and to read the full set of recommendations, see Ripe for Change. 
1 GEOSTAT 2017. National Statistics Office of Georgia. Retrieved from: www.geostat.ge

2 Ibid.

3 National Wine Agency of Georgia. (2017). Retrieved from: http://georgianwine.gov.ge/En/Reports

4 For example, qvevri, an ancient organic method of wine production involving large clay storage vessels.

5 National Statistics Office of Georgia. (2014). 2014 General Population Census Results. Average area of agricultural and non-agricultural land, average number of parcels and average area of parcels operated by family holdings. Retrieved from: http://census.ge/en/results/agro-census/zogadi-informatsia-meurneobebis-shesakheb

6 Czech University of Life Sciences Prague, People in Need, and the Association of Young Economists of Georgia. (2015). Vinery-Wine-making: Agricultural Value Chain in Imereti and Racha regions. Retrieved from: http://enpard.ge/en/wp-content/uploads/2015/05/Market Assessment Wine AYEG ENG.pdf

7 In March 2006, a Russian import ban on Georgian wine was introduced, causing tension and conflict between the two countries. At the time the ban was brought in approximately $70 \%$ of Georgia's total wine exports went to Russia. M. Tsereteli. (2016, 19 April). Banned in Russia: The Politics of Georgian Wine. Retrieved from: https://www.cacianalyst.org/publications/analytical-articles/item/10801-analyticalarticles-caci-analyst-2006-4-19-art-10801.html

8 Ministry of Agriculture of Georgia. (2015). Ministry of Agriculture of Georgia: Annual Report, 2015. Retrieved from: http://www.moa.gov.ge/Download/Files/187

9 EU/Georgia Association Agreement. Retrieved from: https://eeas.europa.eu/headquarters/headquarters-homepage en/9740/EU/Georgia\%20Association\%20Agree$\underline{\text { ment }}$

10 Assessment of the feasibility of establishing/promoting a wine cooperative system in Georgia and its possible benefits for small-scale grape-growers, wineries and the overall economy of the sector - FAO research, 2012.

11 L. Kvariani and S. Ghvanidze. (2015). The role of cooperatives in the Georgian wine industry. ISET, Heilbronn Institute for Applied Market Research. Retrieved from: https://www.bio-conferences.org/articles/bioconf/pdf/2015/02/bioconfoiv2015 03015.pdf

12 Agricultural Cooperatives Development Agency. Cooperatives. Retrieved from: http://acda.gov.ge/index.php/eng/static/118

13 Ibid.

14 European Neighbourhood Programme for Agriculture and Rural Development. Implemented since 2013, the main goal of the ENPARD programme is to reduce rural poverty. Programme assistance is provided to the government and also to NGOs working directly with communities on the ground.

15 ENPARD. (2017, 1 February). ACDA launches new programme in support of viticulture cooperatives. Retrieved from: http://enpard.ge/en/acda-launches-newprogramme-support-viticulture-cooperatives/ 
(c) Oxfam International June 2018

This case study was written by Nana Takvarelia, Tamta Revazishvili, Levan Dadiani and Keti Getiashvili.

For further information on the issues raised in this paper please email policyandpractice@oxfam.org.uk

This publication is copyright but the text may be used free of charge for the purposes of advocacy, campaigning, education, and research, provided that the source is acknowledged in full. The copyright holder requests that all such use be registered with them for impact assessment purposes. For copying in any other circumstances, or for re-use in other publications, or for translation or adaptation, permission must be secured and a fee may be charged. Email policyandpractice@oxfam.org.uk.

The information in this publication is correct at the time of going to press.

Published by Oxfam GB for Oxfam International under

ISBN 978-1-78748-269-2 in June 2018. DOI: 10.21201/2018.2692

Oxfam GB, Oxfam House, John Smith Drive, Cowley, Oxford, OX4 2JY, UK.

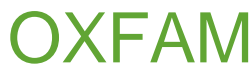

Oxfam is an international confederation of 20 organizations networked together in more than 90 countries, as part of a global movement for change, to build a future free from the injustice of poverty. Please write to any of the agencies for further information, or visit www.oxfam.org. 